\title{
SENYAWA BIOAKTIF PADA ACORUS CALAMUS (L.) DAN PEMANFAATANNYA SEBAGAI OBAT KANKER DAN ANTIMIKROBA
}

\author{
Marina Silalahi \\ marina.silalahi@uki.ac.id \\ Universitas Kristen Indonesia
}

\begin{abstract}
Jerango (Acorus calamus L.) or also known as the sweet flag is a species in the Acoraceae which used as medicine. This article aims to reveal the relationship of secondary metabolites contained of the $A$. calamus with its use as a cure for cancer and anti microbial. This article is based on offline and online media literature. Offline literature used the books, whereas online media used Web, Scopus, Pubmed, and scientific journals. Acorus calamus is an aromatic plant containing the essential oils, especially asarone. The local community Indonesian has long been exploited the Acorus calamus to cure fever, malnutrition, and postpartum mothers. The essential oil of the A. calamus inhibits of microbial growth (bacteria, fungi and yeasts) and inhibits cell growth. The A. calamus is potentially developed as a cancer drug, but its toxicity needs to be further investigated.
\end{abstract}

Key Words: Acorus calamus, asaron, anti cancer, anti microbial.

\begin{abstract}
ABSTRAK
Jerango (Acorus calamus L.) atau yang dikenal juga sebagai sweet flag merupakan salah jenis dalam famili Acoraceae yang dimanfaatkan sebagai obat. Artikel ini bertujuan untuk mengungkapkan hubungan metabolit sekunder yang dikandung $A$. calamus denga pemanfaatannya sebagai obat kanker dan anti mikroba. This article is based on literature offline and online media. Offline literature used the books, whereas online media used Web, Scopus, Pubmed, and scientific journals. Acorus calamus merupakan tumbuhan aromatik yang mengandung essensial oil, khususnya asaron. Masyarakat lokal Indonesia Acorus calamus telah lama dimanfaatkan masyarakat lokal Indonesia sebagai obat demam, malnutrisi dan obat ibu pasca melahirkan. Essensial oil $A$. calamus menghambat pertumbuhan mikroba (bakteri, jamur dan khamir) dan menghambat pertumbuhan sel. Acorus calamus sangat potensial dikembangkan sebagai obat kanker, namun toksisitasnya perlu diteliti lebih lanjut.
\end{abstract}

Kata Kunci: Acorus calamus, asaron, anti kanker, anti mikroba 


\section{PENDAHULUAN}

Jerango (Acorus calamus

L.) atau yang dikenal juga sebagai sweet flag merupakan salah spesies dalam famili Acoraceae. Acorus calamus merupakan salah satu tumbuhan yang memiliki banyak manfaat di antaranya sebagai obat (Silalahi \& Nisyawati 2018), bahan pangan (Dušek et al. 2007), dan juga bermanfaat dalam konservasi lahan. Pai dan McCarthy (2010) menyatakan bahwa Acorus calamus merupakan salah satu spesies tanaman penting secara sosio-ekonomi yang digunakan dalam proyek restorasi lahan basah dapat bertindak sebagai insentif ekonomi untuk konservasi dan restorasi.

Pada awalnya Acorus calamus dimasukkan ke dalam famili Araceae (talas-talasan), namun akhirnya dikeluarkan dari famili tersebut dan dimasukkan ke dalam famili Arocaceae karena memiliki ciri yang sangat berbeda khususnya dalam struktur daun dan rhizomanya. Chang (2010) menyatakan bahwa genus Acorus tidak berhubungan dengan famili Araceae.

Acorus calamus telah lama dimanfaatkan masyarakat lokal Indonesia sebagai obat demam oleh etnis Batak Simalungun (Silalahi et al. 2015a), dan Batak Karo (Silalahi et al. 2015b; Silalahi dan Nisyawati 2018; Silalahi 2016), malnutrisi (Silalahi et al. 2015b) dan obat ibu pasca melahirkan oleh etnis Minangkabau (Khariah et al. 2017). Banyaknya manfaat dari A. calamus mengakibatkan tanaman ini mulai dibudidayakan oleh etnis Batak AngkolaMandailing di pekarangan (Silalahi 2016). Rhizoma merupakan bagian yang dimanfaatkan dalam bentuk tunggal maupun ramuan.

Infeksi mikroba seperti bakteri, khamir dan jamur pada manusia dapat mengakibatkan berbagai penyakit seperti demam dan diare, oleh karena itu tumbuhan yang digunakan untuk mengatasi penyakit tersebut merupakan tumbhan yang 
Silalahi, Senyawa Bioaktif pada Acorus Calamus (I.) dan Pemanfaatannya sebagai Obat Kanker dan Antimikroba

bersifat anti bakteri. Selain infeksi mikroba, kanker juga merupakan salah satu penyebab utama kematian di negara maju maupun berkembang. Kanker merupakan penyakit yang disebakan oleh pertumbuhan sel yang tidak terkendali. Berbagai senyawa sintetis dikembangkan untuk tujuan kemoterapi, namun serig berdampak negatif pada sel yang bukan target. Oleh karena itu penggalian senyawa alternatif yang relatif aman perlu dikembangkan.

Khasiat tumbuhan sebagai bahan obat berhubungan dengan metabolit sekundernya. Dari berbagai laporan penelitian, walaupun rhizoma yang paling sering dimanfaatkan, namun hampir seluruh organ (akar, rhizoma, dan daun) A. calamus mengandung essensial oil. Essensial oil merupakan senyawa kelompok terpenoid khususnya monoterpenoid dan seskuiterpenoid yang mudah menguap pada suhu kamar (Harbone 1987). Hal tersebut mengakibatkan tumbuhanyang memiliki essensial oil menghasilkan oroma yang khas (Dušek et al. 2007). Asaron merupakan essensial utama yang terdapat pada $A$. calamus (Hanelt et al. 2001). Walaupun demikian kandungan essensial oil pada $A$. calamus sangat dipengaruhi oleh faktor internal dan eksternal. Hal tersebut mengakibatkan kandungan essensial oilnya berbeda antara satu daerah dengan daerah lainnya. Faktor internal yang mempengaruhi kandungan asaron dari Acorus calamus terutama kariotipe jumlah kromosom (Hanelt et al. 2001).

Walaupun telah banyak penelitian tentang $A$. calamus namun pembahasan secara konprehensif mengenai pemanfaatannya dan kandungan metabolit sekundernya masih sangat terbatas khusunya pemanfaatannya sebagai anti kanker dan anti mikroba. Artikel ini akan menjadi salah satu sumber referensi untuk pengembangan $A$. calamus sebagai bahan obat. 
Genus Acorus memiliki

\section{METODE}

Tulisan ini didasarkan pada kajian literatur baik secara online dan offline. Offline didasarkan pada berbagai buku literatur seperti Plants Resources of South East Asian dan buku lainnya. Media online didasarkan pada Web, Scopus, Pubmed, dan media on-line yang digunakan untuk publikasi dari berbagai Scientific journals.

\section{PEMBAHASAN}

\section{BOTANI Acorus calamus}

Jerango (Acorus calamus) merupakan salah satu spesies dalam famili dari Acoraceae dimanfaatkan langsung oleh manusia. Acoraceae memiliki sekitar 110 genus dan lebih dari 1800 species (Ganjewala et al. 2011). Nama genus Acorus berasal bahasa Yunani yaitu Acoron (coreon = pupil mata) dan calamus (buluh). Sebagian besar spesies yang termasuk dalam famili Acoraceae merupakan herba yang memiliki rhizoma atau umbi. sekitar 40 spesies dan masih sedikit yang diteliti kandungan kimia diantaranya Acorus calamus, Acorus christophii, Acorus tatarinowii dan Acorus gramineus (Solandin Ait.) (Ganjewala et al. 2011). Acorus calamus menampilkan tingkat plastisitas morfologi yang tinggi dalam pola alokasi biomassa sebagai respons terhadap parameter lingkungan (Pai dan McCarthy 2010). Rimpang $A$. calamus dapat bertahan di tanah nitrogen terbatas meskipun lebih baik di tanah dengan kandungan nitrogen yang lebih besar (Pai dan McCarthy 2010).

Acorus calamus memiliki ciri-ciri antara lain: tanaman menahun (perennial), merayap, dan memiliki banyak percabangan. Rhizoma $A$. calamus menghasilkan aroma, berbentuk silindris, dengan ukuran diameter hingga $2,5 \mathrm{~cm}$, bewarna coklat keunguan di bagian luar dan coklat muda bagian dalam (Balakumbahan et al. 2010). Acorus calamus 
Silalahi, Senyawa Bioaktif pada Acorus Calamus (I.) dan Pemanfaatannya sebagai Obat Kanker dan Antimikroba

memiliki daun tunggal dengan tulang daun utama, vena sekunder, dan tersier menonjol di kedua sisi serta memiliki aroma khas (Balakumbahan et al. 2010). Daun berbentuk pita dan lebarnya berukuran $0,7-1,7 \mathrm{~cm}$, namun rata-rata sekitar $1 \mathrm{~cm}$ (Balakumbahan et al. 2010).

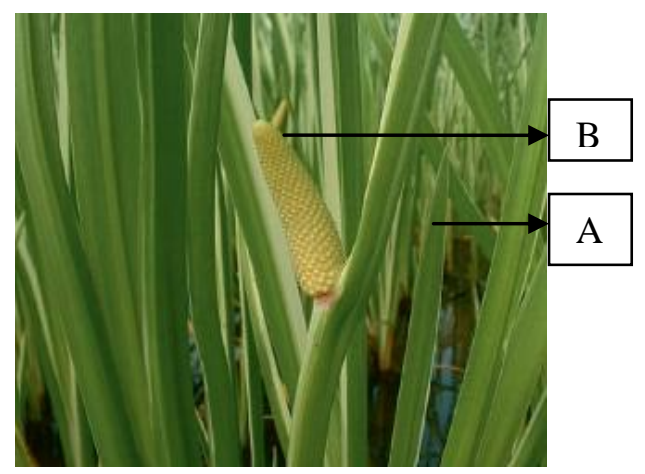

Gambar 1. Acorus calamus L.; A. Daun berbentuk pita dengan tulang daun menonjol;

B. pembungaan yang berbentuk spadiks (Subha et al. 2011)

Daun simpodial dari $A$. calamus lebih pendek dari daun vegetatif. Bagian margin melengkung atau undulate. Tanaman $A$. calamus jarang berbunga dan berbuah dan jika berbunga panjangnya sekitar 3-8 $\mathrm{cm}$, berbentuk silinder, bewarna coklat kehijauan, dan ditutupi oleh banyak dikelilingi oleh duriduri (spikes). Spadika dapat membesar dan panjangnya dapat mencapai 4,9 dan $8,9 \mathrm{~cm}$. Buahnya kecil dan menyerupai buah berry yang mengandung sedikit biji. Bunga muncul pada akhir musim panas, namun demikian kemunculan bunga juga dipengaruhi oleh latitude (Balakumbahan et al. 2010).

Acorus calamus tumbuh liar di tempat berair atau rawarawa dan dapat ditemukan hingga ketinggian $2000 \mathrm{~m}$ (Balakumbahan et al. 2010). Acorus calamus memiliki kromosom dengan jumlah diploid, triploid, dan tetraploid. Acorus calamus dengan jumlah kromosom diploid tumbuh secara alami di Asia (Mongolia dan Siberia) dan Amerika Utara, sedangkan kromosom tetraploid ditemukan di Asia (India, Siberia, dan Jepang), dan kromosom triploid khas di Eropa, Asia, India (wilayah Himalaya), dan Amerika Utara (Chang 2017). Didasarkan pada jumlah kromosom $A$. 
calamus memiliki jumlah kromosom $(n=12)$ yang secara umum dikenal memiliki empat sitotipe yaitu diploid $(2 \times=24)$, triploid $(3 \times=36)$, tetraploid $(4 x$ = 48) dan hexaploid $(6 \times=72)$ ditemukan di alam (Krahulcova 2003).

Karakteristik dari A. calamus memiliki perbedaan anatar satu aksesi dengan aksesi lainnya. Acorus calamus ari aksesi Findlan memeliki karakteristik daun sebagai berikut: rata-rata panjang daun $0.80 \mathrm{~m} \quad(0.74-0.88 \mathrm{~m})$, sedangkan yang berasal dari Canada dan Slovenia memiliki panjang daun 0.85 dan $0.93 \mathrm{~m}$ secara berurutan, dan aksesi Czech memiliki panjang daun 1.0 m (0.62-1.47 m). Lebar daun dari A. calamus dari aksesi di Filandia (Finish, Slovenian dan Canadian) adalah $15 \mathrm{~mm}$ (11.7-18.7 mm). Tidak terdapat perbedaan morfologi antara $A$. calamus yang terdapat di Amerika Utara (diploid) dengan aksesi yang berasal dari Eropa (triploid). Warna daun dari aksesi yang berasal dari Amerika Utara hijau terang dibandingkan dengan yang dari Finland dan Slovenia (Dusek et al. 2007)..

Karakteristik rhizoma juga berbeda yaitu panjang rhizoma di (Finish, Slovenian dan Canadian) yaitu antara 0.18 dan $0.49 \mathrm{~m}$ dengan rata-rata ketebalannya $19.7 \mathrm{~mm}$ (15.7$22.2 \mathrm{~mm}$ ). Walaupun demikian panjang rhizoma sangat dipengaruhi oleh jenis tanah dan kondisi alam lainnya. Rhizoma dari aksesi yang berasal dari Repulik Czech bentuknya tidak bulat namun ellips. Rata-rata ketebalan pada sayatan melintang $18.4 \mathrm{~mm}$ (14.0-25.0 $\mathrm{mm}$ ) dan rata-rata tinggi $15.6 \mathrm{~mm}$ (12.0-21.0 mm) (Dusek et al 2007). Acomus calamus yang dikumpulkan merupakan triploid sehingga tidak menghasilkan sel generatif. Oleh karena itu tanaman dibiakkan melalui rhizoma.

\subsection{SENYAWA BIOAKTIF}

Tumbuhan menghasilkan berbagai senyawa metabolit 
Silalahi, Senyawa Bioaktif pada Acorus Calamus (I.) dan Pemanfaatannya sebagai Obat Kanker dan Antimikroba

sekunder yang memiliki efek farmakologis seperti alkaloid, phenolik, flavonoid, dan terpenoid/isoprenoid (Devi and Ganjewala 2009). Berbagai tumbuhan menghasilkan senyawa isoprenoid (monoterpenoid dan seskuiterpenoid) yang mudah menguap yang disebut dengan tumbuhan aromatik. Tumbuhan aromatik ditandai dengan aroma khas, yang juga sering digunakan untuk membedakan jenis-jenis tumbuhan.

Kandungan metabolit sekunder pada tumbuhan termasuk essensial oil khususnya asaron dipengaruhi oleh faktor internal dan eksternal. Faktor internal yang mempengaruhi kandungan asaron dari Acorus calamus terutama kariotipe jumlah kromosom (Hanelt et al. 2001; Venskutonis \& Dagilyte 2003). Kandungan asaron berbanding lurus dengan jumlah kariotipenya, oleh karena itu semakin besar kariotipenya makan kadar asaronnya semakin tinggi. Kariotipe $A$. calamus yang tumbuh liar di alam memiliki kromosom diploid, triploid, tetraploid, dan hexaploid (...........). Kariotipe diploid yang dikenal juga sebagai var. americanus memiliki jumlah kromosom $(2 n=$ 24) terdapat America Utara dan Siberia hanya mengandung $\beta$ asarone rendah di dalam rhizomanya. Kariotipe triploid var. Calamus memiliki kromosom ( $3 n$ = 36) terdapat di Europa Tengah dan Kashmir, mengandung $\beta$ asarone (9-13\%), sedangkan tetraploid disebut var. angustata atau var. angusta memiliki kromosom $\quad(4 n=48)$ mengandung $\beta$-asarone (7096\%) (Rost 1979; Hanelt et al. 2001). Dusek et al. (2007) melaporkan bahwa Acorus calamus var. calamus dari Finland mengandung sekitar $\beta$ asarone $(1,50 \%)$ dari berat keringnya, sedangkan yang dari Czech Republic hanya mengandung $1,91 \%$.

Jenis essensial oil pada daun dan rhizoma $A$. calamus bervariasi dalam jenia maupun kadarnya. Parki et al (2017) 
menyakan beberapa jenis essensial oil yang terdapat di daun dan rhizoma A. calamus antara lain: bornyl acetate, limonene; 3 trans- $\beta$-ocimene, linalool; shyobunone; $\alpha$-copaene; $\beta$ - elemene; aristolene; $E$ caryophyllene; calarene; $\alpha-$ humulene; a-muurolene; germacrene $\quad \mathrm{D} ; \quad$ Z-methyl isoeugenol; viridiflorene; dehydroxy-isocalamendiol; $\delta$ cadinene; kessane; a-cadinene; $\alpha$-calacorene; $\alpha$-elemol; $\quad \beta$ calacorene; elemicin; spathulenol; caryophyllene oxide; $\beta$-asarone; asaronaldehyde; Zisoelemicin; $\alpha$-asarone; $\quad 2,4,6$ trimethoxyacetophenone methyl; aspidinol; 2,4,5trimethoxybenzoic acid, phytol, asam palmitat.

Komposisi essensial oil dari akar $A$. calamus antara lain: B-gurjunene $(28,0 \%), \quad(Z) \quad$ asarone $(13,7 \%)$, aristolene $(13,4 \%)$, dan $(E)$-asarone $(7,9 \%)$ (Verma et al. 2015). Komposisi minyak akar sangat berbeda dari komposisi rimpang dan minyak daun $A$. calamus (Verma et al.
2015). Komposisi dan konsentrasi esensial oil dari Acorus calamus yang dikumpulkan di Lithuania berbeda antara rimpang dan daun. Rimpang kering $A$. calamus mengandung sekitar $1,20 \pm$ $0,12 \%$ essensial oil sedangkan daun hanya 0,56-1,01\% (Venskutonis \& Dagilyte 2003). Daun $A$. calamus mengandung sekitar 66 jenis essensial oil, sedangkan di rhizoma hanya mengandung 55 jenis (Venskutonis \& Dagilyte 2003). $\delta$-Asarone $\quad[(Z) \quad$-asarone] merupakan essensial oil utama di daun dengan konsentrasi 27,4$45,5 \%$, sedangkan acorenone memrupakan essensial dominan dalam rimpang dengan konsentrasi 20,86\% diikuti oleh isocalamendiol $(12,75 \%)$ (Venskutonis \& Dagilyte 2003).

\subsection{MANFAAT}

Metabolit sekunder yang dihasilkan tumbuhan telah lama dimanfaatkan manusia khusunya untuk tujuan pengobatan. Dalam pengobatan tradisional di Asia 
Silalahi, Senyawa Bioaktif pada Acorus Calamus (I.) dan Pemanfaatannya sebagai Obat Kanker dan Antimikroba

dan Eropa, Acorus calamus pertumbuhan

Penicillium digunakan untuk mengurangi selera makan, diare, gangguan saluran pencernaan, bronchitis, sakit didada, dan gangguan syaraf (Chandra and Prasad 2017). Berdasarkan hasil bioessaynya senyawa kimia yang terdapat pada $A$. calamus memiliki aktivitas biologi seperti anti bakteri, antifungal (Devi and Ganjewala 2009; Ravindran and Balachandran 2004), anti yeast (Devi and Ganjewala 2009) dan anti-cancer (Haghighi et al. 2017). Bahsan selanjutnya akan difokuskan pada biaoktivitas $A$. calamus sebagai anti mikroba dan anti kanker.

\subsubsection{Antimikroba}

Antimikroba merupakan senyawa yang dapat menghambat pertumbuhan atau senyawa yang dapat merusak strukur mikroba. Rhizoma $A$. calamus memiliki aktivitas anti bakteri dan anti jamur (Rita et al. 2017; Devi and Ganjewala 2009), namun daya hambatnya berbeda (Devi and Ganjewala 2009). Ekstrak $A$. calamus menghambat

(Devi and Ganjewala 2009), Streptococcus mutants (Vijayakumar et al. 2015), dan Candida albicans (Rita et al. 2017), namun tidak mampu menghambat pertumbuhan Eschericia coli (Devi and Ganjewala 2009). .

Ekstrak etil asetat daun $A$. calamus memiliki daya hambat pertumbuhan fungi dan khamir (20-28 mm dan 22-25 mm secara berurutan) lebih tinggi dibandingkan dengan ekstrak akar (18-25 mm dan 20-23 mm secara berurutan) (Devi and Ganjewala 2009). Konsentrasi hambat minimum/ Minimum inhibitory concentration (MIC) daun dan rhizoma sebesar 2-4 $\mathrm{mg} / \mathrm{ml}$ untuk jamur kecuali untuk Penicillium chrysogenum, sedangkan untuk menghambat pertumbuhan khamir relatif lebih tinggi yaitu $4-5$ dan $6-8 \mathrm{mg} / \mathrm{ml}$ secara berurutan. MIC untuk bakteri relatif tinggi yaitu $16-42$ $\mathrm{mg} / \mathrm{ml}$ (Devi \& Ganjewala 2009). Senyawa $\alpha$ dan $\beta$ asarone merupakan senyawa antimikroba 
yang mampu menghambat pertumbuhan jamur, khamir dan bakteri (Devi \& Ganjewala 2009). Konsentrasi hambat minimum dari esensial oil terhadap $C$. albicans adalah $1 \%$ dengan penghambatan 7,83 $\mathrm{mm}$ (Rita et al. 2017). Patogen jamur seperti penyebab Candida albicans infeksi oportunistik yang disebut kandidiasis kulit, mukosa, dan organ pada manusia. C. albicans sering menginfeksi mulut atau vagina ketiga sistem kekebalan tubuh kurang baik (Rita et al. 2017).

\subsubsection{Antikanker}

Kanker merupakan salah satu penyebab kematian tertinggi di negara maju dan berkembang. Pemanfaatan obat sintetis yang digunakan dalam kemoterapi memiliki keterbatasan terutama karena efek racunnya pada jaringan non-target, oleh karena permintaan untuk perawatan alternatif, dan agen antikanker alami dianggap sebagai pilihan terbaik. Berbagai obat anti kanker yang diperagangkan berasal dari tanaman seperti alkaloid (vinblastin, vincristine, vinorelbine), epipodophyllotoxins (etoposide, etoposide fosfat, teniposida), taxanes (paclitaxel dan docetaxel), dan turunan camptothecin (irinotecan dan topotecan) (Cragg et al. 2007).

Metabolit sekunder tumbuhan yang dimanfaatkan sebagai obat kanker adalah senyawa yang yang memiliki aktivitas sebagai anti proliferative atau yang menghambat pembelahan sel (Gali-Muhtasib and Bakkar, 2002). Essential oil yang terdapat pada $A$. calamus menghambat proliferasi sel kanker sebesar $120 \mu \mathrm{g} / \mathrm{ml}$, yang setara dengan 5FU (obat conventional anti-cancer) (Haghighi et al. 2017). Ekstrak dan esensial oil $A$. calamus memiliki efek sitotoksik yang signifikan pada sel kanker dibandingkan dengan sel normal setelah 48 jam perlakuan (Haghighi et al. 2017). Ekstrak dan minyak esensial $A$. calamus menyebabkan G1 tertahan (Haghighi dkk 2017). 
Silalahi, Senyawa Bioaktif pada Acorus Calamus (I.) dan Pemanfaatannya sebagai Obat Kanker dan Antimikroba

\begin{abstract}
Acorus calamus digunakan
untuk mengobati sistem percenaan di Asia sejak 2000 yang lalu (Haghighi et al. 2017). Hasil penelitian menunjukkan bahwa essensial oil dari $A$. calamus menghambat pertumbuhan HUVEC cells (Haghighi et al. 2017). Ekstrak etanol dan metanol dari rhizoma A.calamus secara signifikan menghambat proliferasi dari sel kanker lambung manusia tergantung pada dosis dan waktu dan cara pemakaian. Pemakaian pada dosis tinggi dan waktu yang lebih lama memiliki efek sitotoksisitas yang signifikans. Ekstrak rhizoma dan essensial oil dari A. calamus menghambat pertumbuhan sel dari kanker lambung namun tidak signifikan, namun penghambat proliferasi sel normal (Haghighi et al. 2017) .
\end{abstract}

\section{KESIMPULAN}

1. Masyarakat lokal Indonesia Acorus calamus telah lama dimanfaatkan masyarakat lokal Indonesia sebagai obat demam, malnutrisi dan obat ibu pasca melahirkan.

2. Essensial oil A. calamus menghambat pertumbuhan mikroba (bakteri, jamur dan khamir) dan menghambat pertumbuhan sel.

\section{ACUAN PUSTAKA}

Balakumbahan, R., Rajamani, K. \& Kumanan, K. (2010). Acorus calamus: An overview. Journal of Medicinal Plants Research 4(25): 2740-2745.

Chandra, D. \& Prasad, K. (2017). Phytochemicals of Acorus calamus (Sweet flag). Journal of Medicinal Plants Studies 5(5): 277-281.

Chang, P.S. (2010) Flora of China. 23:1-2. Available from: http:// www.efloras.org

Cragg, G.M., Newman, D.J. \& Weiss, R.B. (1997). Coral reefs, forest and thermal vents: the worldwide exploration of nature of nature for novel antitumor agents. Sem. Oncol. 24: 156-163.

Dušek, K., Galambosi, B., Hethelyi, E.B., Korany, K., \& Karlová, K. (2004). Morphological and chemical variations of 
sweet flag (Acorus calamus L.) in the Czech and Finnish gene bank collection. Hort. Sci. (Prague) 34 (1): 17-25.

Ganjewala, D., \& Srivastava, A.K. (2011). An update on chemical composition and bioactivities of Acorus species. Asian J. Plant Sci., 1-8.

Gali-Muhtasib, H. \& Bakkar, N. 2002. Modulating cell cycle: current applications and prospects for future drug development. Curr Cancer Drug Targets 2: 309-336.

Haghighi, S.R., Asadi, M.H., Akrami, H. \& Baghizadeh, A. (2017). Anticarcinogenic and antiangiogenic properties of the extracts of Acorus calamus on gastric cancer cells. Avicenna $J$ Phytomed 7 (2): 145-156.

Hanelt P., 2001. Mansfeld's Encyclopaedia of Agricultural and Horticultural Crops. 5th vol., 1st ed. Berlin, Springer: 2317-2318.

Harborne, J.B. (1987). Metode fitokimia : Penuntun cara modern menganalisis tumbuhan, Ed. II. Diterjemahkan oleh Kosasih Padmawinata dan
Iwang Soedira. ITB Press, Bandung: $x+354 \mathrm{hlm}$.

Khairiah, A. (2017). Etnomedisin dan Nilai Ekonomi Tumbuhan Obat Pada Etnis Minangkabau di Kecamatan IX Koto Sungai Lasi, Solok, Sumatra Barat. Tesis. Departement Biologi, FMIPA, Universitas Indonesia, Depok. Indonesia

Krahulcova, A. (2003). Chromosome numbers in selected monocotyledons. Perslia Praha 75:97-113.

McGaw, L.J., Jäger, A.K. \& van Staden, J. (2002) Isolation of $\quad \beta$-asarone, an antibacterial and anthelmintic compound, from Acorus calamus in South Africa, South African. J. Bot. 68: 31-35.

Ogra, R.K., Mahapatra, P., Sharma, U.K., Sharma, M., Sinha, A.K. \& Ahuja, P.S. (2009) Indian calamus (Acorus calamus L.): not a tetraploid. Curr Sci 97: 1644-1647.

Pai, A. \& McCarthy, B.C. (2010). Suitability of the Medicinal Plant, Acorus calamus L., for Wetland Restoration. Natural Areas Journal 30(4): 380-386.

Raina, V.K., Srivastava, S.K. \& Syamasunder, K.V. (2003) Essential oil composition of 
Silalahi, Senyawa Bioaktif pada Acorus Calamus (I.) dan Pemanfaatannya sebagai Obat Kanker dan Antimikroba

Acorus calamus L. from the lower region of the Himalayas. Flav Frag J 18: 18-20.

Rost, L.C.M. \& Bos, R. (1979) Biosystematic investigations with Acorus calamus

L.
Communication.

Constituents of essential oils, Planta Med. 27: 350361.

Ravindran, P.N. \&, Balachandran, I. (2004) Underutilized medicinal spices (1). Spice India 17:1-14.

Rita, W.S., Kawuri, R. \& Swantara, I.M.D. (2017). The Essential oil contents of jeringau (Acorus calamus L.) rhizomes and their antifungal activity against Candida albicans. Journal of Health Sciences and Medicine 1(1): 33-37.

Rost, L.C.M.

Biosystematic Investigations with Acorus L. (Araceae).

Communication. Essential Oil Contents. In: Proceedings of the Koninklijke Nederlandse Academie van

Wetenschappen 82: 113126.

Silalahi, M. \& Nisyawati. (2018). The ethnobotanical study of edible and medicinal plants in the home garden of Batak Karo sub-ethnic in North Sumatra, Indonesia. Biodversitas 19(1): 229238.

Silalahi, M. (2016). Diversity of medicinal plants in homegardens in Tanjung Julu village, North Sumatra, Indonesia. International Journal of Biological Research Volume 4(1): 78-82.

Silalahi, M., Nisyawati, Walujo, E.B., \& Supriatna, J., 2015a. Local knowledge of medicinal plants in subethnic Batak Simalungun of North Sumatra, Indonesia, Biodiversitas 16(1), 44-54.

Silalahi, M, Nisyawati, Walujo, E.B., Supriatna, J. \& Mangunwardoyo, W., 2015b. The local knowledge of medicinal plants trader and diversity of medicinal plants in the Kabanjahe traditional market,

North Sumatra, Indonesia. Journal of Ethnopharmacology 175, 432-443.

Todorova, M.N., Ognyanov, I.V. \& Shatar, S. (1995) Chemical composition of essential oil from Mongolian Acorus calamus L. rhizomes. $J$ Essent Oil Res 7: 191-193. 
JDP Volume 11, Nomor 1, April 2018: 95-108

Vijayakumar, K.B., Bannimath, G., Koganti, V.S. \& lye, V.B. (2016). Gas Chromatographic Method for Analysis $\beta$-Asarone in Rhizome extracts of Acorus calamus and Their Microbiological Evaluation. Pharm Methods 7(2): 121126

Venskutonis, P.R. \& Dagilyte, A. (2005). Composition of
Essential Oil of Sweet Flag

(Acorus calamus L.) Leaves at Different Growing Phases. Journal of Essential Oil Research 15(5): 313-318

Verma, R.S., Padalia, R.C. \& Chauhan, A. (2015). Chemical composition of root essential oil of Acorus calamus L. 38(2): 121-125 